\title{
Identification and Prioritisation of Mine Pollution Sources in a Temperate Watershed Using Tracer Injection and Synoptic Sampling
}

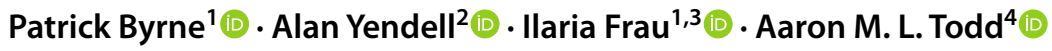

Received: 14 September 2020 / Accepted: 9 June 2021 / Published online: 29 September 2021

(c) The Author(s) 2021

\begin{abstract}
Identifying and prioritising mine sites for remediation is challenging due to inherently complex hydrological systems and multiple potential sources of mine pollution dispersed across watersheds. Understanding mine pollution dynamics in wet temperate watersheds is particularly challenging due to substantial variability in precipitation and streamflows, which increase the importance of diffuse sources. A tracer dilution and synoptic sampling experiment was conducted in a mined watershed in Scotland to identify the main sources of mine pollution, the relative importance of point and diffuse sources of pollution, and the potential benefits of mine site remediation to stream water quality. Using high spatial resolution metal loading datasets, the major $\mathrm{Zn}$ and $\mathrm{Cd}$ source areas were identified as point sources of mine water predominantly located in the upper part of the watershed. In contrast, the main sources of $\mathrm{Pb}$ were diffuse sources of mine tailings and wastes located in the lower part of the watershed. In the latter case, mobilisation of $\mathrm{Pb}$ occurred primarily from a section of braided wetland and an uncapped tailings area. Importantly, diffuse sources of mine pollution were found to be the dominant source of $\mathrm{Pb}$, and an important source of $\mathrm{Zn}$ and $\mathrm{Cd}$, even under steady-state streamflow conditions. Mass balance calculations suggest that treatment of the main mine water sources in the upper watershed and capping of the tailings deposit in the lower watershed could reduce stream trace metal concentrations by approximately $70 \%$. These data support the development of conceptual models of mine pollution dynamics in wet temperate watersheds. These conceptual models are important as they: (1) help prioritise those mine sites and features for remediation that will deliver the most environmental and socio-economic benefit, and; (2) provide a means to quantify the importance of diffuse pollution sources that may increase in importance in the future as a result of changes in precipitation patterns in temperate watersheds.
\end{abstract}

Keywords Mining $\cdot$ Metal $\cdot$ Scotland $\cdot$ Water quality $\cdot$ Diffuse pollution $\cdot$ Remediation

Patrick Byrne

p.a.byrne@ljmu.ac.uk

Alan Yendell

alan.yendell@sepa.org.uk

Aaron M. L. Todd

887577@ Swansea.ac.uk

1 School of Biological and Environmental Sciences, Liverpool John Moores University, Liverpool L3 3AF, UK

2 Contaminated Land Specialist, Scottish Environment Protection Agency, Angus Smith Building, Maxim 6, Parklands Avenue, Eurocentral, Lanarkshire ML1 4WQ, UK

3 Built Environment and Sustainable Technologies (BEST) Research Institute, Faculty of Engineering and Technology, Liverpool John Moores University, Liverpool L3 3AF, UK

4 Department of Geography, Swansea University, Swansea SA2 8PP, UK

\section{Introduction}

Many years of metal mining in the United Kingdom (UK) has left behind many kilometres of abandoned underground mines and substantial quantities of waste that can contaminate watercourses (Byrne et al. 2012; Jarvis and Mayes 2012). Contamination from abandoned metal mines is recognised as a major cause of failure to achieve environmental objectives set out in statutory River Basin Management Plans (DEFRA 2014; Jarvis and Mayes 2012). As such, identification and remediation of mine pollution sources is one of the major challenges facing environmental managers in the UK.

With multiple potential sources of pollution across a watershed and the often extensive nature of historical mining operations, the task of identifying and quantifying sources 
of mine pollution is complex (Byrne et al. 2012). Whilst point sources of mine pollution (e.g. drainage from adits and shafts) are generally easily identified and quantified, there is currently no systematic approach in the UK for identifying diffuse sources of mine pollution (e.g. surface mine waste drainage, groundwater efflux, hyporheic zone mobilisation) or for discriminating the relative importance of point and diffuse sources at the river watershed scale (Mayes et al. 2009). Diffuse sources of mine pollution are particularly problematic in the UK due to the temperate-oceanic climate, which drives substantial variability in precipitation and river and stream flows (Jarvis et al. 2019). Recognising the limitations of existing methodologies, a major recommendation of the UK's Department for Environment, Food and Rural Affairs (Defra) Prioritisation of abandoned non-coal mine impacts on the environment project was to develop methodologies for systematic scoping of river watersheds affected by mine pollution for more informed decision-making (Jarvis and Mayes 2012).

The tracer dilution and synoptic sampling approach for source apportionment of mine pollution was developed by the US Geological Survey (USGS) and has been extensively used in the USA to inform mine site remediation under the Abandoned Mine Lands Initiative (Kimball et al. 2002; Runkel et al. 2017; Walton-Day et al. 2007). It uses high spatial resolution synchronous (or synoptic) water quality and flow measurements at multiple stream and inflow locations across a watershed to provide spatially detailed assessments of pollutant fluxes. Flow is measured using a conservative tracer (typically sodium bromide or lithium chloride) that is injected into the stream above the mine workings at a constant rate and concentration. Over time, all portions of the stream (including the hyporheic zone) become fully mixed with the tracer to reach a plateau concentration. Decreases in tracer plateau concentrations with distance downstream reflect dilution by point and diffuse source inflows of water, whether they be surface or groundwater. The advantage over typical methods of streamflow estimation (e.g. velocityarea, weir, gulp-injection, acoustic doppler velocimetry) is that flow measurements are based on dilution of a tracer that is fully mixed in the stream (including the hyporheic zone). Physical flow measurements in high-energy mountain streams are compromised by irregular stream cross-sections (velocity-area method) and failure to capture hyporheic flow (weir and gulp-injection methods), potentially leading to significant errors in flow estimates. In addition, when streamflow is quantified by tracer concentration, there is no need to measure flow at each location and therefore, sampling effort per location is substantially reduced. This allows sampling at many more locations and over a much larger area for the same effort, thereby increasing both accuracy and detail of metal loading estimates for decision-making purposes. The results provide greater spatial coverage, better resolution (samples are closer together), and more accurate streamflow (and therefore metal-loading) estimates, allowing discrimination and quantification of point and diffuse source inputs for remediation decision-making.

The tracer dilution and synoptic sampling method has previously been applied principally in arid settings where watershed wetness and streamflows are generally low (precipitation / potential evapotranspitraion $(\mathrm{P} / \mathrm{PET} \leq 0.03$ to 0.2; Zhou et al. 2015) and point sources of mine pollution typically dominate watershed metal loading (De Giudici et al. 2019; Runkel et al. 2013). There is therefore a real paucity of information on metal sources and transport dynamics in wetter climates such as the UK where higher watershed wetness (P/PET $\geq 1$; Zhou et al. 2015) and greater hydrological connectivity (between the watershed and the stream) increases the importance of diffuse sources of mine pollution. Recognising the challenges of identifying sources of mine pollution in temperate-oceanic watersheds, this work sought to demonstrate the tracer dilution and synoptic sampling methodology in an exemplar temperate study site in Scotland. Understanding mine pollution dynamics in temperate watersheds is also important as projected changes in precipitation patterns due to climate change will likely modify sources and transport processes (Byrne et al. 2020). Our specific objectives were to: (1) locate and rank the principal sources of mine pollution in the study watershed; (2) discriminate the relative importance of point and diffuse sources of mine pollution under steady-state flow conditions, and; (3) estimate potential improvements in stream water quality following hypothetical mine site remediation scenarios. Ultimately, this work improves our understanding of mine pollution dynamics in wet, temperate watersheds and provides the scientific evidence to better inform decisions on mine site remediation in these environments.

\section{Methodology}

\section{Study Area}

Due to the presence of significant and accessible galena and sphalerite veins in the surrounding rock formations, the villages of Leadhills and Wanlockhead are well known for being the centre of lead production in Scotland for many hundreds of years. Wanlockhead is situated in the southern uplands terrane, a glaciated landscape comprising the Kirkcolm Formation (sandstones and siltstones), Crawford Group (mudstones, cherts and lava flows), Moffat Shale Group (dark mudstones), and the Portpatrick Formation (volcaniclastic greywacke sandstones) (Floyd 2003). The primary ore mineralisation is related to the Caledonian Orogeny 
resulting in polymetallic hydrothermal veins predominantly of metal sulphides including galena $(\mathrm{PbS})$ and sphalerite $(\mathrm{ZnS})$. These are mainly located within the Portpatrick Formation with some localised extension into the Kirkcolm Formation. The mineral veins generally trend north-northwest to south-southeast.

The Wanlock Water rises to the east of the village of Wanlockhead at an elevation of $\approx 435 \mathrm{mAOD}$. From there, the river flows $\approx 8 \mathrm{~km}$ to the confluence with the Crawick Water, in the catchment of the River Nith. The study area encompasses a $2 \mathrm{~km}$ long section of the Wanlock Water below Wanlockhead (Fig. 1). Within this study area, the major tributary and mine water inflows are the Bay Mine Adit, Whyte's Cleuch, Glenglass Stream, Glenglass Level, Limpen Burn, Shieling Burn, Glenmarchhope Burn and Sowen Burn (The Coal Authority 2014, Scottish Environment Protection Agency (SEPA) 2011). The wider landscape in the study area comprises upper moorland with steep slopes rising to $588 \mathrm{mAOD}$. Annual rainfall exceeds 1500 $\mathrm{mm} \mathrm{a}^{-1}$ (Rowan et al. 1995).

\section{Tracer Injection and Synoptic Sampling}

Metal loads were quantified under steady-state flow conditions using the tracer-dilution (to estimate streamflow) and synoptic sampling method (Byrne et al. 2017; Runkel et al. 2013). Sampling was undertaken under $\approx \mathrm{Q} 30$ flow conditions based on scaling by SEPA from Hall Bridge gauging stations on the River Nith downstream of the study site.

Sodium bromide $(\mathrm{NaBr})$ was used as a tracer in this study due to its known conservative behaviour in circumneutral stream water (Dzombak and Morel 1990). A continuous $\mathrm{NaBr}$ injection $\left(40,000 \mathrm{mg} \mathrm{L}^{-1}\right.$ at $\left.152 \mathrm{~mL} \mathrm{~min}^{-1}\right)$ was initiated in the Bay Mine Adit discharge (WW-0000-INJ in Fig. 1) at 15:45 on 9 Sept. 2019. The injection was terminated at 16:10 on 13 Sept. 2019 following completion of the synoptic sampling. It should be noted that the injection site was on the Bay Mine Adit inflow to the Wanlock Water. Approximately $50 \mathrm{~m}$ upstream of the Bay Mine Adit inflow, the Wanlock Water was dry due to loss of surface water to the underground mine workings and/or the stream bed

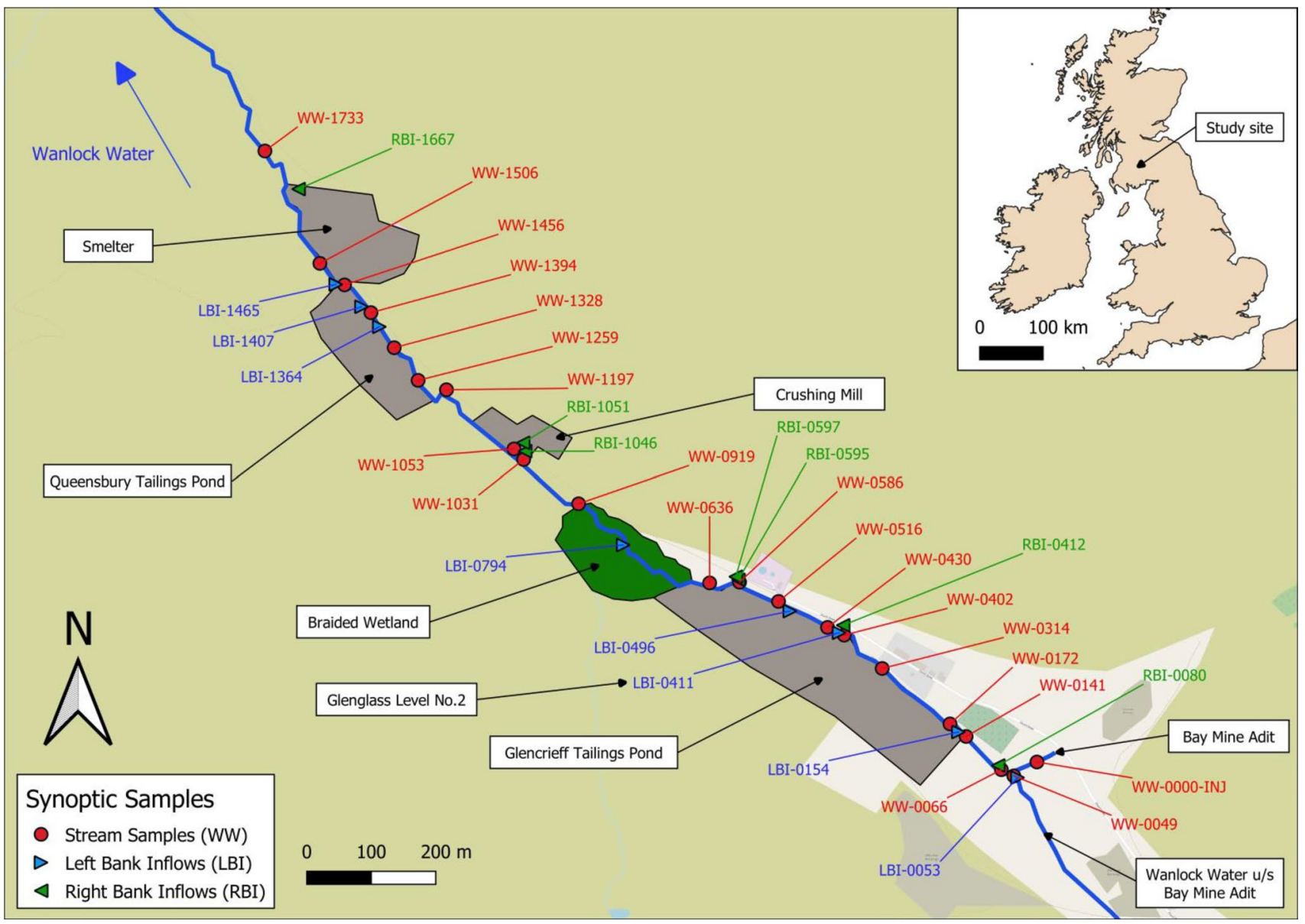

Fig. 1 Stream and inflow sample sites. Numbers associated with samples represent the distance (in metres) below the tracer injection point (WW-0000-INJ) 
and, for this reason, the Bay Mine Adit is represented as the start of the study reach in the preceding analyses and interpretations.

Synoptic samples were collected at 21 stream sites, 17 inflow sites, and one mine water site (Fig. 1, Supplemental Table S-1) on the morning of 13 Sept. when tracer concentrations had reached a steady-state plateau. Inflow sites included visible tributary-type inflows and more ill-defined flows such as riparian seeps and springs. Samples were transported to a central processing site within minutes of collection. On-site processing included filtration $(0.45 \mu \mathrm{m})$, measurement of $\mathrm{pH}$ and specific conductivity, and preservation of samples for metals analysis. Anion concentrations were determined from filtered, unacidified samples by ion chromatography and are reported in Table S-2. Aliquots for cation analysis were acidified to $\mathrm{pH}<2$ with ultrapure $1 \%$ $\mathrm{HNO}_{3} \mathrm{v} / \mathrm{v}$. Total recoverable and filtered (some colloidal material may have passed through the $0.45 \mu \mathrm{m}$ filter) cation concentrations were determined from unfiltered and filtered samples, respectively, by inductively coupled plasma-mass spectroscopy (ICP-MS). Trace element concentrations are reported for $\mathrm{Al}, \mathrm{As}, \mathrm{Ca}, \mathrm{Cd}, \mathrm{Cu}, \mathrm{Cr}, \mathrm{Fe}, \mathrm{K}, \mathrm{Mg}, \mathrm{Mn}, \mathrm{Na}, \mathrm{Ni}$, $\mathrm{Pb}$, and $\mathrm{Zn}$ (Tables S-2, S-3 and S-4). Alkalinity was determined from filtered, unacidified samples. Anion concentrations are reported for $\mathrm{Cl}, \mathrm{Br}$, and $\mathrm{SO}_{4}$ (Table S-2).

While most metal results for trace metals were within the laboratory accreditation limits, the $\mathrm{Zn}$ analysis reported apparent inaccuracies with filtered data noted to have significantly higher $(25 \%$ to $>100 \%$ ) concentrations than the total recoverable data. This issue was specific to the $\mathrm{Zn}$ data and is considered to be a result of the on-site filtering process. As $\mathrm{Zn}$ exists almost exclusively in the dissolved phase in the Wanlock Water, total recoverable $\mathrm{Zn}$ concentrations are considered a good proxy for dissolved concentrations, and therefore total recoverable $\mathrm{Zn}$ is referred to as 'dissolved' from here onwards (see Supplmentary Information).

\section{Estimating Streamflow}

Decreases in the concentrations of tracer plateau concentrations with distance downstream reflect dilution of the tracer as surface and/or subsurface drainage results in increases in streamflow. Streamflow estimation at each synoptic site relates the injected tracer characteristic to the observed dilution (Kimball et al. 2002) (Eq. 1):

$Q=\frac{Q_{I N J} C_{I N J}}{\left(C_{P}-C_{B}\right)}$

where $\mathrm{Q}_{\mathrm{INJ}}$ is the injection rate, $\mathrm{C}_{\mathrm{INJ}}$ is the tracer injectate concentration, $\mathrm{C}_{\mathrm{P}}$ is the tracer plateau concentration at the synoptic site, and $\mathrm{C}_{\mathrm{B}}$ is the tracer background concentration in the stream water. Streamflow estimates and observed tracer dilution are illustrated in Fig. 2.

\section{Loading Analysis and Source Apportionment}

The study reach was divided into 20 segments demarcated by the 21 stream synoptic sampling sites. Metal loads were calculated as the product of the streamflow estimate and the metal concentration (Table S-5). Cumulative instream load is equal to the sum of all increases in metal load (Kimball et al. 2002). For a given stream segment, the cumulative instream load is increased if the metal load increased, and held constant if the metal load decreased. The cumulative instream load provides an estimate of the total metal load added to the stream over the entire study reach whereas the instream metal load represents the net amount of loading after chemical reactions such as adsorption and precipitation. A net increase in cumulative instream load suggests addition of metal mass to the stream. The percent contribution of each source is given by (Eq. 2):

$\%$ Contribution $=\frac{100 \triangle \text { load }}{(L 2-L 1)}$

where $\Delta$ load is the within-segment increase, and L1 and L2 are the cumulative instream loads at the upstream and downstream ends of the study reach, respectively. Percent contributions from multiple segments were grouped to represent the total contributions from the main source areas within Wanlock Water. Comparison of cumulative instream load with instream load provides a means of estimating net attenuation of metals over the length of the study reach.

Where stream segments show an increase in metal load, calculation of 'effective inflow concentrations' provides a means to determine if an observed inflow is representative of all inflow waters entering the segment (Kimball et al. 2002). If observed inflow concentrations exceed effective inflow concentrations, there are likely more dilute inflow waters entering the stream segment in addition to the sampled inflow, or there is some attenuation occurring in that reach. Conversely, high concentration waters are entering the stream segment when effective inflow concentrations exceed observed inflow concentrations. Under the assumption of conservative solute transport, effective inflow concentrations $\left(\mathrm{C}_{\mathrm{L}}\right)$ can be calculated as (Eq. 3):

$C_{L}=\frac{\left(Q_{D} C_{D}-Q_{U} C_{U}\right)}{\left(Q_{D}-Q_{U}\right)}$

where $\mathrm{Q}$ is discharge, $\mathrm{C}$ is concentration, and ${ }_{\mathrm{U}}, \mathrm{D}$, and $\mathrm{L}$ represent upstream, downstream, and lateral inflow values, respectively. 
Fig. 2 a Spatial profile of bromide concentrations and streamflow (derived from the tracer-dilution method) b Spatial profile of $\mathrm{pH}$ at stream and inflow sites. Location of major inflows indicated with vertical dashed lines. Shaded areas $=$ braided wetland ( 600-900 $\mathrm{m})$ and Queensbury Tailings Pond ( 1300-1450 m)
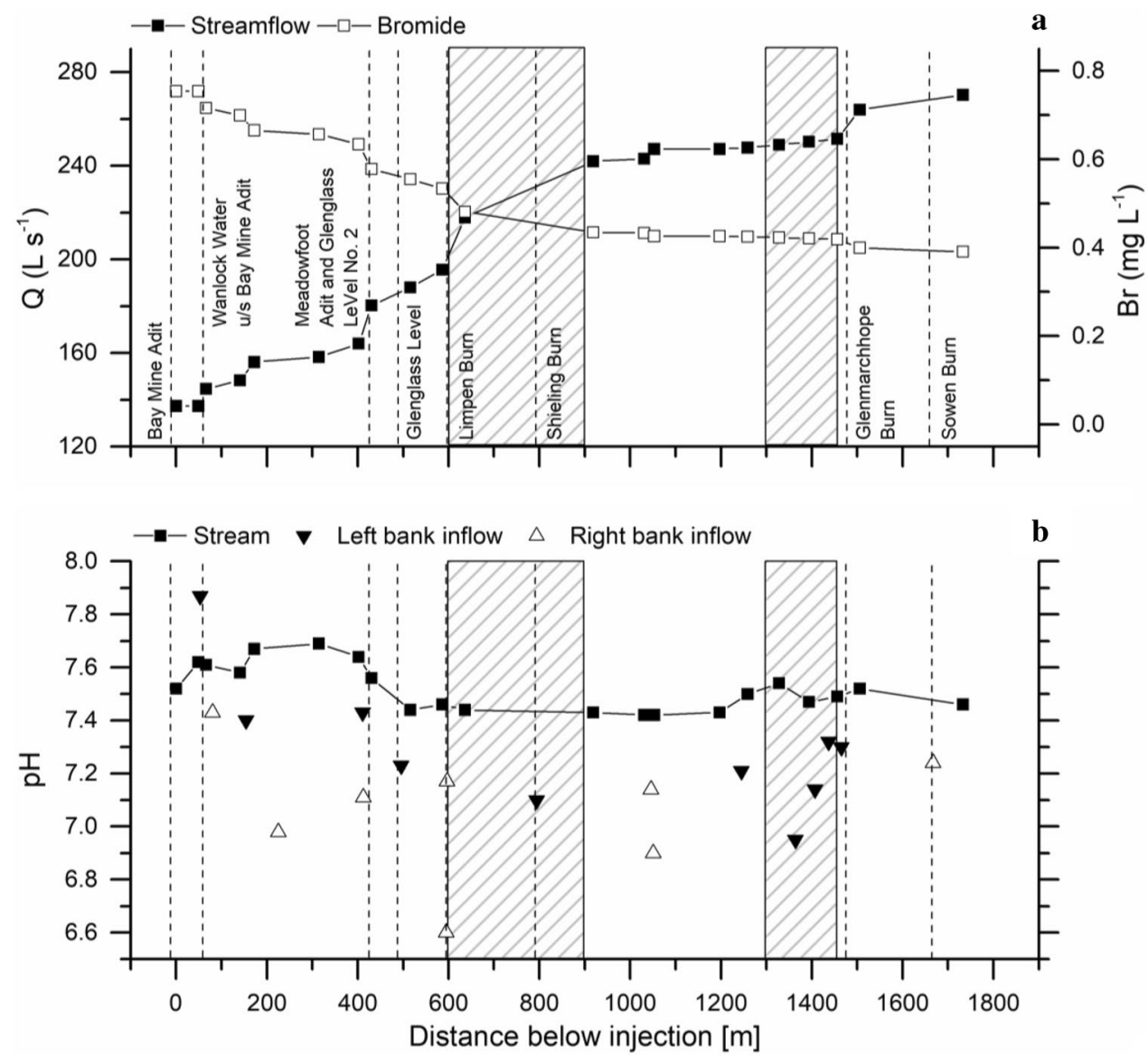

\section{Results and Discussion}

\section{Streamflow, pH, and Metal Concentrations}

Streamflow increased with distance downstream from $\approx 137 \mathrm{~L} \mathrm{~s}^{-1}$ just downstream of the tracer injection site on the Bay Mine Adit to $\approx 270 \mathrm{~L} \mathrm{~s}^{-1}$ downstream of Sowen Burn at the end of the study reach (Fig. 2a). The Wanlock Water upstream of the Bay Mine Adit accounted for just 5\% of the increase in streamflow along the reach. Four major inflows accounted for $56 \%$ of the increase in streamflow in the study reach at the time of sampling. These were the Meadowfoot Adit (RBI-0412) and Glenglass Level no. 2 (LBI-0411) (12.3\%), Limpen Burn (RBI-0597) (16.8\%), Shieling Burn (LBI-0794) including unsampled inflows from the braided wetland area (18\%), and Glenmarchhope Burn (LBI-1465) $(9.4 \%)$. Minor inflows $(\approx 5 \%$ contribution or less) included Whytes Cleuch (RBI-0080), Glenglass Stream (LBI-0154), Glenglass Level (LBI-0496), Sowen Burn (RBI-1667), and various drainages from the crushing mill (RBI-1046) and Queensbury tailings pond (LBI-1364; LBI-1407; LBI-1437). Together, stream segments with sampled inflows comprised $88 \%$ of the total flow measured in the stream, indicating some unidentified or unknown dispersed surface and / or subsurface water inputs entering the stream in segments with no sampled inflows.

Spatial profiles of $\mathrm{pH}$ for stream sites and inflows are illustrated in Fig. 2b. Stream pH values ranged from 7.4 to 7.7 with higher values generally occurring at sites opposite the Glencrieff tailings pond $(\approx 150$ to $600 \mathrm{~m}$ below the injection site). Inflow $\mathrm{pH}$ values were typically lower than the stream values (range $=6.6-7.9$ ) and possibly represent lower $\mathrm{pH}$ water sources from mine workings and organic-rich and saturated soils.

In this discussion of metal concentrations and loads, we focus on three metals $(\mathrm{Pb}, \mathrm{Zn}$, and $\mathrm{Cd})$ that fail environmental quality standards (EQS) in the Wanlock Water. We discuss dissolved Cd data only due to the close correspondence between total recoverable and dissolved concentrations. As a result of the issues with $\mathrm{Zn}$ analysis noted already, total recoverable concentrations of $\mathrm{Zn}$ are presented but referred to as dissolved concentrations. Lastly, total recoverable and dissolved concentrations of $\mathrm{Pb}$ are presented due to the large difference observed between fractions for this metal. Instream dissolved $\mathrm{Zn}, \mathrm{Pb}$, and $\mathrm{Cd}$ concentrations exceeded EQS (annual average for $\mathrm{Cd}=0.09 \mu \mathrm{g} \mathrm{L}{ }^{-1}$, based on hardness of $50-100 \mathrm{mg} \mathrm{L}^{-1} \mathrm{CaCO}_{3}$; $\mathrm{Pb}$ and $\mathrm{Zn}$ are based on bioavailability and calculated by SEPA as $\mathrm{Pb}=1.2 \mu \mathrm{g} \mathrm{L}^{-1}$ and 

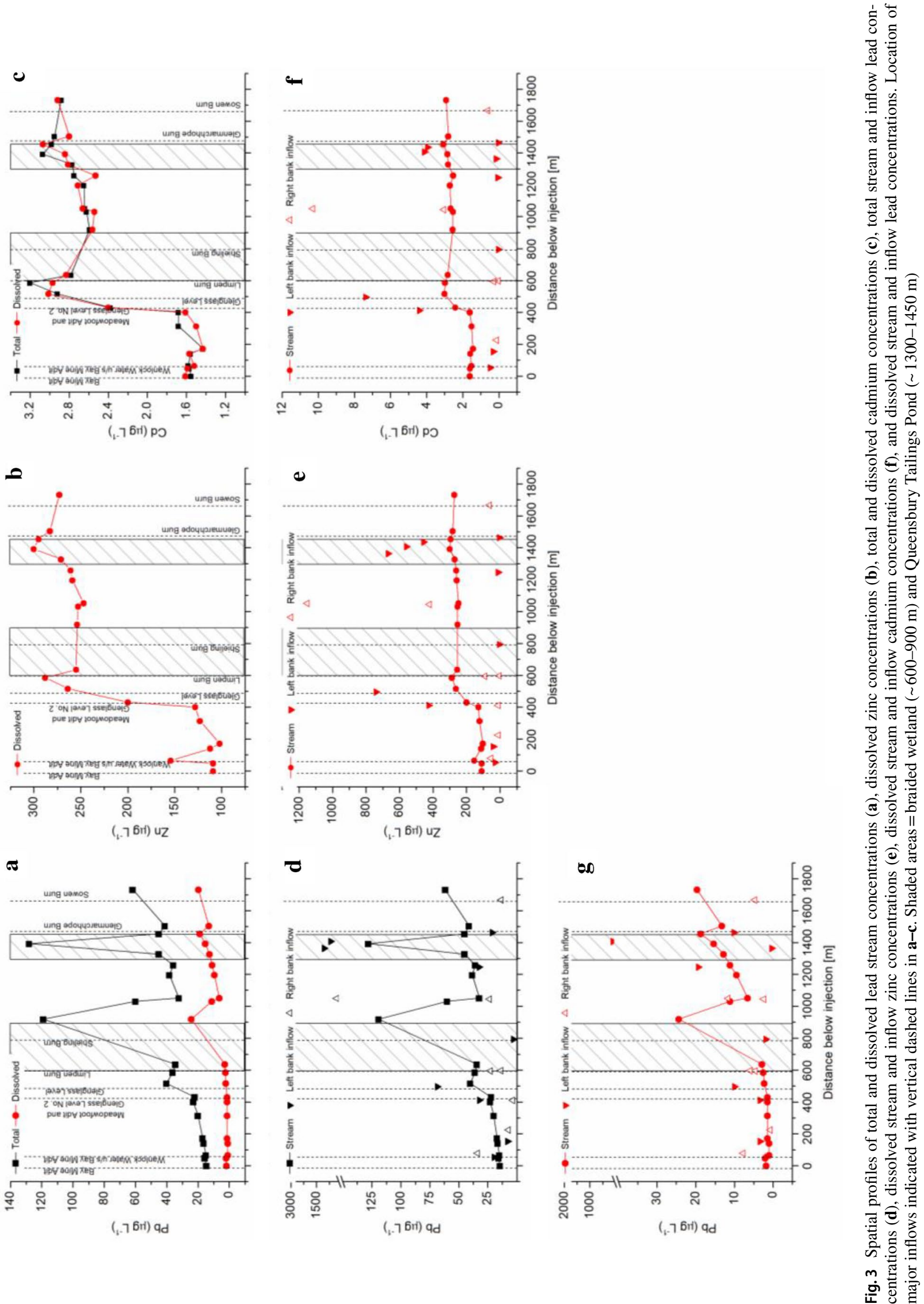
$\mathrm{Zn}=11.3 \mu \mathrm{g} \mathrm{L}^{-1}$ ) for the entirety of the study reach (Fig. 3). Mean dissolved concentrations of these contaminants over the $2 \mathrm{~km}$ study reach were $(\mathrm{Pb}) 8.2 \mu \mathrm{g} \mathrm{L}{ }^{-1}$ (range $=1.0-24 \mu \mathrm{g}$ $\mathrm{L}^{-1}$ ), (Zn) $217 \mu \mathrm{g} \mathrm{L}^{-1}$ (range $=102-300 \mu \mathrm{g} \mathrm{L}^{-1}$ ), and $(\mathrm{Cd})$ $2.4 \mu \mathrm{g} \mathrm{L}^{-1}$ (range $\left.=1.4-3.1 \mu \mathrm{g} \mathrm{L}^{-1}\right)$. Lead concentrations generally increased with distance downstream. Superimposed on this trend were marked increases associated with the braided wetland area ( $\approx 600$ to $900 \mathrm{~m})$ and the Queensbury tailings pond $(\approx 1300$ to $1400 \mathrm{~m}$ ). This pattern was particularly evident for total recoverable concentrations but was also found in the dissolved concentration data. The increase associated with the wetland does not appear to be related to Shieling Burn and instead is thought to be due to other unsampled inflows and / or resuspension of $\mathrm{Pb}$-rich sediments in the wetland area. The increase in $\mathrm{Pb}$ concentrations next to the Queensbury tailings pond corresponded to very high total and dissolved concentrations in the left bank inflows (LBI-1364; LBI-1407; LBI-1437) draining this area.

As the injection site was located on the Bay Mine Adit it can be seen that the concentration of $\mathrm{Zn}$ and $\mathrm{Cd}$ were elevated well above environmental standards at the start of the study reach. A substantial increase in both $\mathrm{Zn}$ and $\mathrm{Cd}$ concentrations occurred between $\approx 400$ and $600 \mathrm{~m}$ (Fig. 3) and appeared to be associated with left bank inflows (LBI0411-Glenglass Level no. 2 and LBI-0496-Glenglass Level) draining the Glencrieff tailings pond. A slight decrease in $\mathrm{Zn}$ and $\mathrm{Cd}$ concentrations occurred at $\approx 600 \mathrm{~m}$, possibly due to dilution by water from Limpen Burn. A further increase in stream concentrations occurred next to the Queensbury tailings pond and appeared to be associated with left bank inflows (LBI-1364; LBI-1407; LBI-1437) draining this area. However, calculation of effective inflow concentrations for
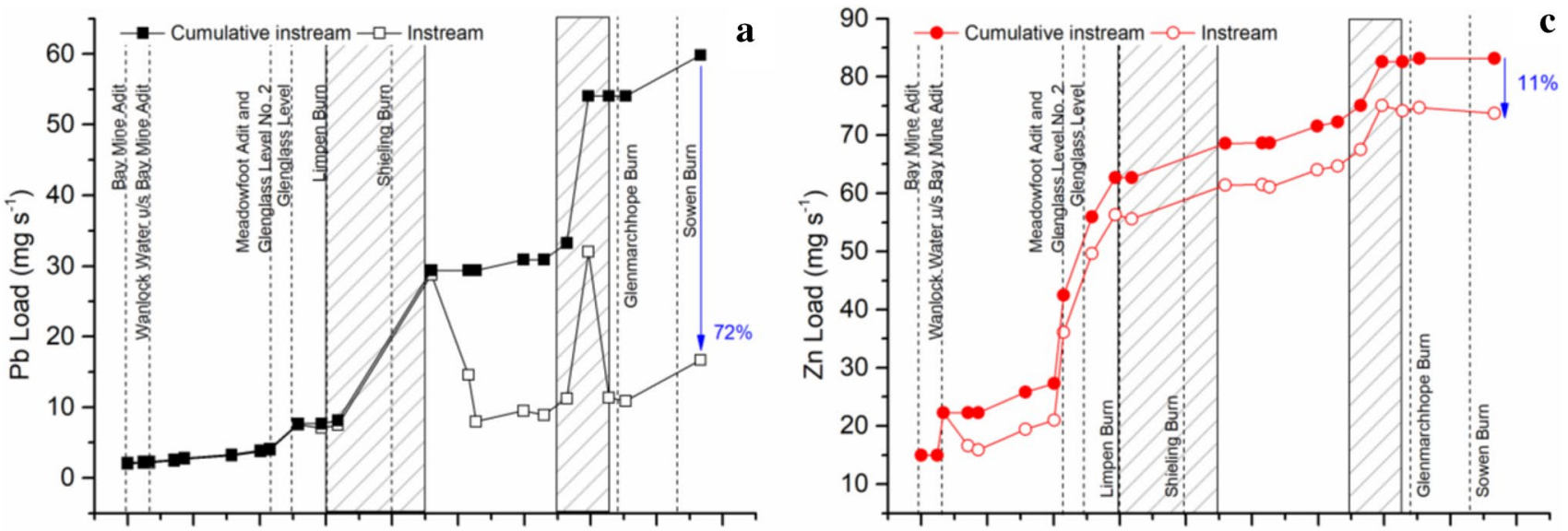

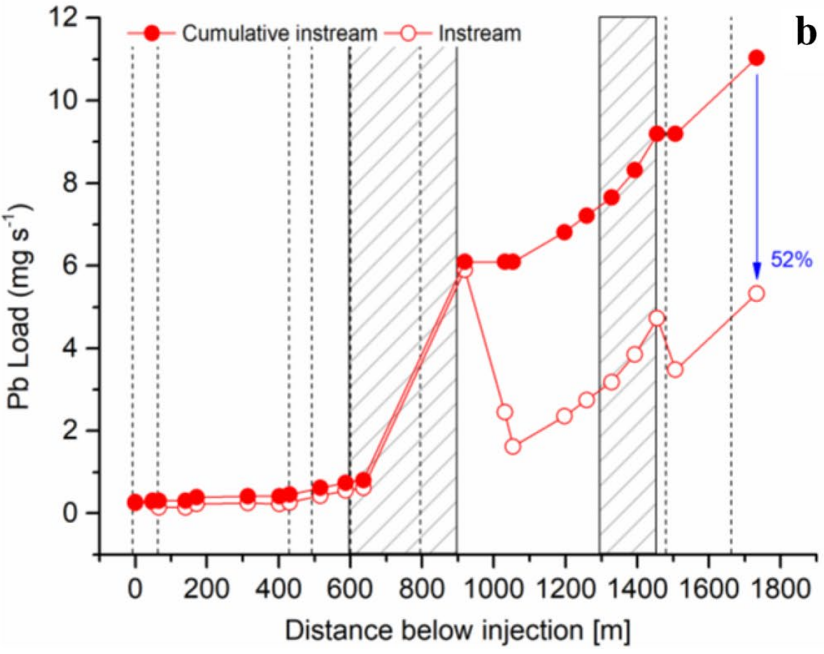

Fig. 4 Spatial profiles of total $\mathbf{a}$ and dissolved $\mathbf{b}$ cumulative instream and instream lead loads, and dissolved cumulative instream and instream zinc c and cadmium loads d. Location of major inflows indicated with vertical dashed lines. Shaded areas $=$ braided wetland

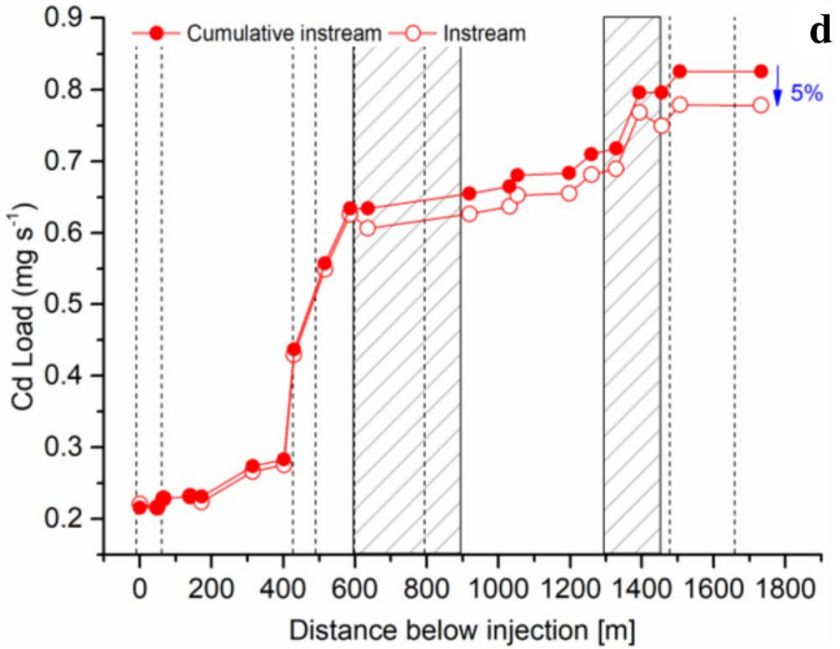

( 600-900 m) and Queensbury Tailings Pond ( 1300-1450 m). Blue arrow indicates the total attenuation [\%] of metal contaminants over the study reach due to physical and chemical processes 
the two reaches receiving these three inflows (WW-1328 to WW-1394 and WW-1394 to WW-1456) indicates a substantial proportion of the change in stream concentrations ( $>90 \% \mathrm{Zn}$ and $\mathrm{Cd}$ ) was due to unsampled, possibly diffuse subsurface, inflows. Although substantial attenuation of $\mathrm{Pb}$ occurred throughout the study reach, elevated $\mathrm{Zn}$ and $\mathrm{Cd}$ concentrations were maintained throughout the study reach due to the general conservative behaviour of these elements at circumneutral pH (Byrne et al. 2012; Gozzard et al. 2011; Hermann and Neumann-Mahlkau 1985).

\section{Spatial Pattern in Metal Loading}

Changes in metal loads in each stream segment obtained from synoptic sampling of water chemistry and tracerderived streamflow are illustrated in Fig. 4 and Table S-5. Spatial loading profiles for total recoverable $\mathrm{Pb}$ loads indicate that two stream segments, ending at 919 and $1394 \mathrm{~m}$, accounted for most of the stream loading (36 and 35\%, respectively) (Fig. 4a). These two segments capture the braided wetland area and some of the drainage (LBI-1364) from the Queensbury tailings pond. Other important (> 5\% contribution) sources of total recoverable $\mathrm{Pb}$ were the segments ending at $516 \mathrm{~m}$ (which receives the Glenglass Level inflow (LBI-0496)) and at $1733 \mathrm{~m}$ (which receives drainage from Sowen Burn (RBI-1667) and possibly the smelter). The loading profile for dissolved $\mathrm{Pb}$ (Fig. 4b) attributes $48 \%$ of the loading to the segment capturing the braided wetland area and $17 \%$ of loading to the segment capturing Sowen Burn and the smelter. Other important ( $>5 \%$ contribution) sources of dissolved $\mathrm{Pb}$ were the segments ending at $1197 \mathrm{~m}$ (downstream of the crushing mill), and 1394 and $1456 \mathrm{~m}$ (both receiving drainage from the Queensbury tailings pond). The relative importance of Shieling Burn vs. unsampled inflows in the braided wetland area warrants investigation, as does the importance of Sowen Burn vs. unsampled inflows that may drain the old smelter site. However, effective inflow concentrations cannot be calculated for $\mathrm{Pb}$ due to its non-conservative behaviour in the study reach. That being said, the low concentrations of $\mathrm{Pb}$ (Tables S-3 and S-4) observed in Shieling Burn (LBI-0794) suggest that most of the loading in this stream segment was derived from mobilisation of $\mathrm{Pb}$ from sediment deposited in the wetland, rather than from Shieling Burn. In contrast, relatively high $\mathrm{Pb}$ concentrations (Tables S-3 and S-4) in Sowen Burn (RBI1667) may indicate this inflow drains mine waste materials associated with the smelter, though it is unlikely that this inflow alone accounts for the observed increase in loading in the segment ending at $1733 \mathrm{~m}$.

The spatial loading profile for dissolved Zn (Fig. 4c) illustrates that the stream segment ending at $49 \mathrm{~m}$ (the first synoptic sample site located at Bay Mine Adit) contributed $18 \%$ of $\mathrm{Zn}$ stream loading and was the starting load at the upstream end of the study reach. The second and third largest sources were the stream segments ending at 430 and $516 \mathrm{~m}$, contributing 18 and $16 \%$ of stream Zn loading, respectively. These two stream segments encompass inflows from the Meadowfoot Adit/Glenglass Level no. 2 (LBI-0411 and RBI-0412) and the Glenglass Level (LBI0496), respectively. A very similar pattern of stream loading was evident for dissolved Cd (Fig. 4d). The Bay Mine Adit was the principal source, accounting for $26 \%$ of stream $\mathrm{Cd}$ loading. The segments ending at 430 and $516 \mathrm{~m}$ contributed 19 and $15 \%$ of stream Cd loading, respectively.

The difference between the instream metal load and the cumulative instream metal load at the last synoptic sample site (WW-1733) can be used to quantify the attenuation that occurred along the study reach. Attenuation of total and dissolved $\mathrm{Pb}$ was 72 and 52\%, respectively, indicating both physical (settling) and chemical (adsorption and precipitation) processes were important in the removal of $\mathrm{Pb}$ from the water column. Attenuation of dissolved $\mathrm{Zn}$ and $\mathrm{Cd}$ over the entire length of the study reach was 11 and 5\%, respectively, indicating that these metals behaved more conservatively in the study reach, with most of the $\mathrm{Zn}$ and $\mathrm{Cd}$ that entered the stream over the study reach being transported downstream of the last synoptic sample site. The only substantial zone of $\mathrm{Zn}$ attenuation (7\%) was in the stream segment ending at $141 \mathrm{~m}$. This segment receives surface inflow from Whyte's Cleuch (RBI-0080) on the right bank. The $\mathrm{pH}$ of this inflow was 7.8, which may account for $\mathrm{Zn}$ sorption and/or precipitation at this point. Whytes Cleuch is known to be dry in periods without rainfall and attenuation of $\mathrm{Zn}$ may only be intermittent as a result. Geochemical modelling could potentially confirm the mechanisms of attenuation here.

\section{Major Source Areas}

If one or more adjacent stream segments showed an increase in load, these segments were grouped to indicate loading from a major source area, which may correspond to a particular mine site or landscape feature. Seven major source areas were identified this way (Fig. 5). The largest source area for total recoverable $\mathrm{Pb}$ was the Queensbury tailings ponds (39\%) (including three left bank inflows: LBI-1364, LBI-1407, and LBI-1465). The second and third largest source areas were the braided wetland area (including Shieling Burn: LBI-0794) (36\%) and the stream segment ending at $1733 \mathrm{~m}(10 \%)$, including Sowen Burn (RBI-1667) and most likely diffuse drainage subsurface from the smelter. The largest source area for dissolved $\mathrm{Pb}$ was the braided wetland (48\%), followed by the Queensbury tailings ponds (22\%), and the stream segment ending at $1733 \mathrm{~m}(17 \%)$. The braided wetland area most likely functions as a depositional area 

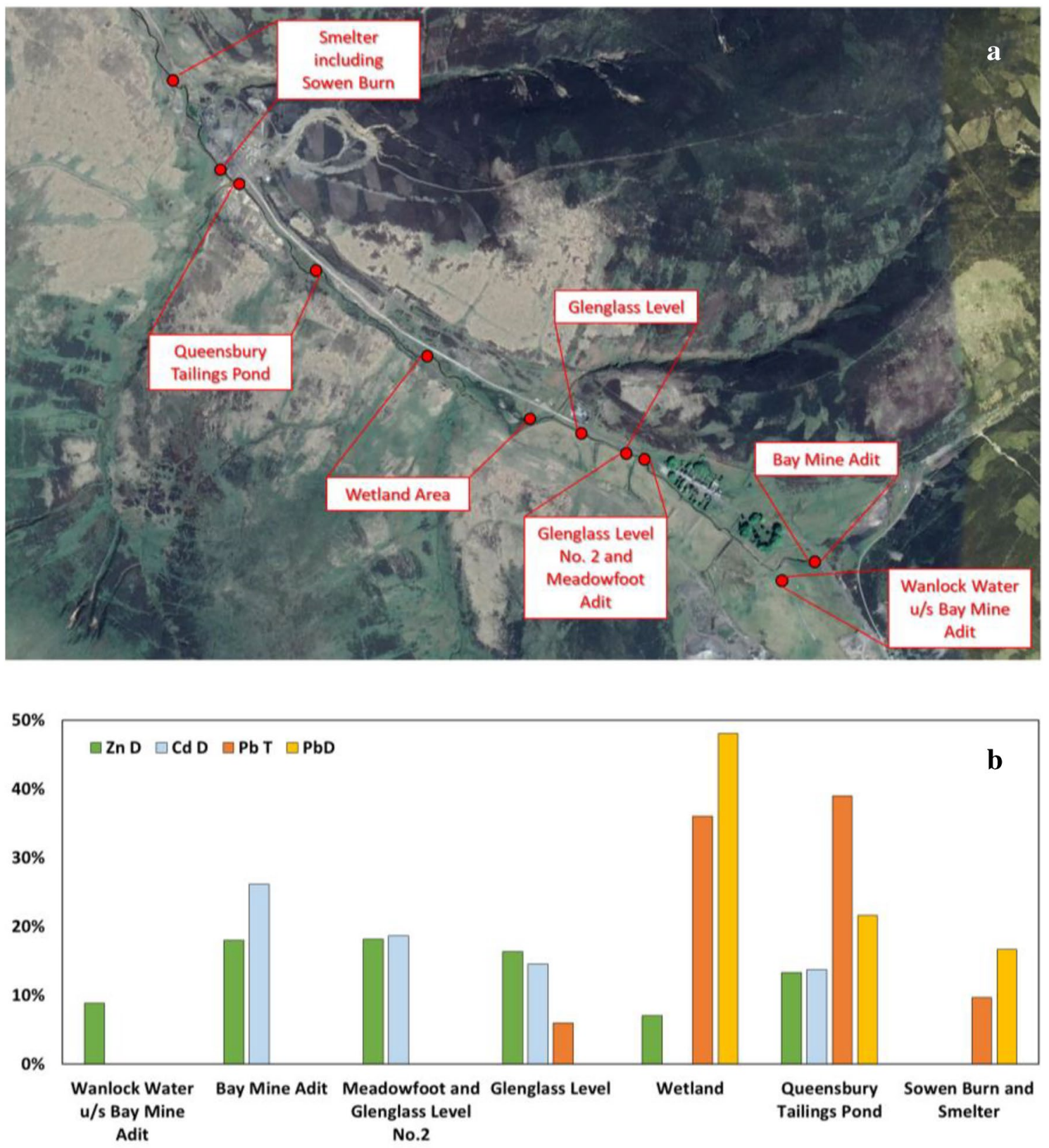

Fig. 5 Percent contribution and location of source areas to overall metal loads within the Wanlock Water study reach. a Location of the main source areas within the study reach. b Dissolved $(\mathrm{Pb}, \mathrm{Zn}, \mathrm{Cd})$

for aqueous and particulate $\mathrm{Pb}$ during low flows, as has been observed elsewhere for $\mathrm{Pb}$ (De Giudici et al. 2017) and other metals (Dean et al. 2013). The wetland area may also be contaminated from wastes deposited during the operational period of the mines. The dominance of the particulate phase during sampling suggests that $\mathrm{Pb}$ mobilisation and transport from the wetland is related to high stream velocities that mobilise streambed sediments (Palumbo-Roe et al. 2012). However, the increase in dissolved $\mathrm{Pb}$ may be related to complexation with dissolved and total recoverable $(\mathrm{Pb})$ loading from the main source areas. $D$ dissolved load and $T$ total recoverable load in the bar chart legends

and/or colloidal organic matter, which has been shown to account for $\mathrm{Pb}$ in dissolved (i.e. $<0.45 \mu \mathrm{m}$ filtered) fractions (Aiken et al. 2011; Chen et al. 2018). Unfortunately, dissolved organic matter (DOM) was not measured as part of this study so we cannot confirm this hypothesis; however, it is reasonable to assume elevated DOM concentrations were present where the stream passes through the wetland area. At the Queensbury tailings ponds and the Sowen Burn/smelter source areas, mobilisation of $\mathrm{Pb}$ is probably related to physical erosion and runoff of tailings 
during wet periods (Byrne et al. 2013) as well as leaching of streamside waste materials and subsequent emergence in the stream as diffuse subsurface drainage (Lynch et al. 2017, 2018).

The two largest source areas for dissolved $\mathrm{Zn}$ were the Bay Mine adit (18\%) and the stream segment including the Meadowfoot Adit and Glenglass Level no. 2 (18\%). The third most important source area was the Glenglass Level (16\%). The fourth most important source area was the Queensbury tailings ponds (13\%). The Wanlock Water upstream of the Bay Mine adit was the fifth most important source area (9\%). This is important as the Wanlock Water upstream of the Bay Mine adit (LBI-0053) was largely dry during our sampling campaign (stream water was lost to ground a few metres downstream of our sample point). The increase in $\mathrm{Zn}$ load noted between WW-0049 and WW-0066 was therefore likely to be related to stream water and/or groundwater from further upstream in the Wanlock Water that had infiltrated mined strata and re-emerged in this stream segment.

The major source areas for dissolved $\mathrm{Cd}$ were the same as for dissolved $\mathrm{Zn}$, which reflects the underlying geochemical similarity of these elements. The largest source area for dissolved Cd was the Bay Mine Adit (26\%). The second and third largest source areas were the stream segments including the Meadowfoot adit and Glenglass Level no. 2 (19\%), and the Glenglass Level (14\%). Similar to Zn, a fourth major source area was the Queensbury tailings pond (14\%). As discussed previously, the $\mathrm{Zn}$ and $\mathrm{Cd}$ concentrations measured in inflows draining the Queensbury tailings ponds cannot account for the observed changes in stream $\mathrm{Zn}$ and $\mathrm{Cd}$ concentrations along these tailings ponds. Calculation of effective inflow concentrations for the stream segments receiving these inflows indicates unsampled high $\mathrm{Zn}$ and $\mathrm{Cd}$ concentration ( $>90 \% \mathrm{Zn}$ and $\mathrm{Cd}$ was unsampled) water was entering the stream here. This is conjectured to be diffuse subsurface inflow and very small surface water inflows from this feature.

\section{Point vs. Diffuse Source Contributions}

Consideration of the relative importance of diffuse and point sources of mine pollution is necessary to inform the design of remedial solutions and to evaluate potential changes in the location and magnitude of sources under different streamflow conditions.

Point sources identified in the study area included drainage from mine adits and levels. An important source of metal loading was also water originating from the upper Wanlock Water (LBI-0053) above the Bay Mine adit. Diffuse sources identified in the study area included erosion of mine tailings/waste, remobilisation of mine waste deposited in the wetland area, and subsurface drainage of tailings/waste (as demonstrated by effective inflow concentrations of $\mathrm{Zn}$ and $\mathrm{Cd}$ for the stream segments next to the Queensbury tailings ponds). These findings are important as they demonstrate that diffuse sources, typically thought to be related to rainfall runoff events (Byrne et al. 2013; Jarvis et al. 2019), can also be important sources at the watershed-scale under steady flow conditions in a temperate watershed. Other potential diffuse sources in our study reach include the hyporheic zone, where remobilisation of sediment-bound metals to dissolved phases has been established in other studies (Palumbo-Roe et al. 2012). Diffuse sources can be both persistent and episodic in nature and can vary in importance in response to rainfall and streamflow. For example, drainage from the Queensbury tailings ponds might be expected to increase in importance as a source during periods of high rainfall, when erosion and runoff rates may be greatest (Gozzard et al. 2011; Jarvis et al. 2019; Onnis et al. 2018). The mode of entry to the stream channel could be via a complex combination of episodic point and diffuse source inflows. Conversely, subsurface water contaminated by leaching from mine tailings, such as that which may exist where the stream passes the Queensbury tailings ponds, may be more persistent in temperate watersheds.

Figure 6 compares cumulative instream metal loads and the cumulative loads from point sources (mine water) and diffuse sources (mine waste) of mine pollution, based on the results of this study. For this analysis, diffuse sources include the braided wetland area, the Queensbury tailings pond, and stream segments with no observed inflows but where metal load increased. Point sources include all identified mine water (adit) and tributary inflows. This analysis indicates the dominance of point sources of dissolved $\mathrm{Zn}$ and $\mathrm{Cd}$ (67 and 75\%, respectively) in the upper part of the study area (above $\approx 516 \mathrm{~m}$ ) where mine water discharges are important. Diffuse sources of total and dissolved $\mathrm{Pb}(78$ and $74 \%$, respectively), and to a lesser extent $\mathrm{Zn}$ and $\mathrm{Cd}$ (33 and 25\%, respectively), are most important in the lower part of the study area (below $\approx 516 \mathrm{~m}$ ) where mobilisation in the braided wetland area and drainage from the uncapped Queensbury tailings ponds increase stream metal loading.

This study was conducted under estimated Q30 streamflow conditions based on scaling from a downstream gauge on the River Nith. As far as the authors are aware, this is the highest steady-state streamflow for which high spatial resolution stream metal loadings have been determined. Even so, it is worth noting that mining-affected watersheds are hydrologically-complex systems and that changes in rainfall, runoff, and streamflow could change the location and importance of the identified mine pollution sources (Gozzard et al. 2011; Pietroń et al. 2017; Thornton and Walsh 2001). However, based on the preceding analyses, variability in mine pollution sources and stream metal loading due to 
Fig. 6 Spatial profiles of cumulative instream loads (total, diffuse source and point source) for a total recoverable lead, b dissolved lead, c dissolved zinc and $\mathbf{d}$ dissolved cadmium
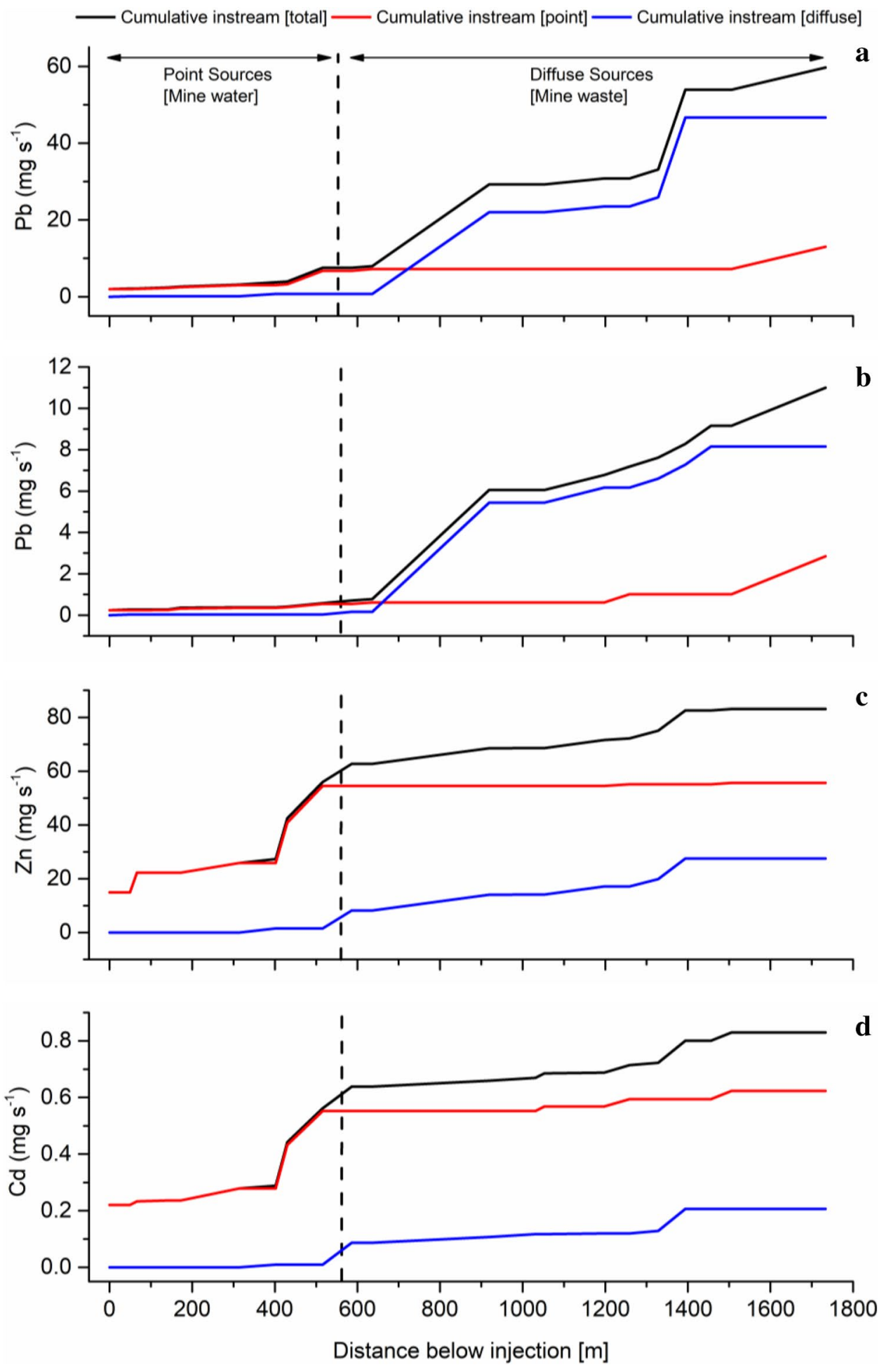
Table 1 Potential improvements in filtered $\mathrm{Zn}$ and $\mathrm{Cd}$ in the Wanlock Water under different hypothetical remediation scenarios

\begin{tabular}{|c|c|c|c|c|c|}
\hline & Scenario \#1 & Scenario \#2 & Scenario \#3 & Scenario \#4 & Scenario \#5 \\
\hline \multicolumn{6}{|l|}{ Dissolved Zn } \\
\hline Environmental Quality Standard $\left[\mu \mathrm{g} \mathrm{L}^{-1}\right]$ & 11.3 & 11.3 & 11.3 & 11.3 & 11.3 \\
\hline Pre-remediation concentration $\left[\mu \mathrm{g} \mathrm{L}^{-1}\right]$ & 273 & 273 & 273 & 273 & 273 \\
\hline Pre- remediation load $\left[\mathrm{mg} \mathrm{s}^{-1}\right]$ & 73.8 & 73.8 & 73.8 & 73.8 & 73.8 \\
\hline Load from source $\left[\mathrm{mg} \mathrm{s}^{-1}\right]$ & 15.0 & 13.6 & 15.1 & 13.1 & 56.7 \\
\hline Post- remediation load $\left[\mathrm{mg} \mathrm{s}^{-1}\right]$ & 58.8 & 60.2 & 58.7 & 60.6 & 17.0 \\
\hline Post-remediation concentration $\left[\mu \mathrm{g} \mathrm{L}^{-1}\right]$ & 217.6 & 222.8 & 217.2 & 224.4 & 63.0 \\
\hline Concentration change post-remediation [\%] & 28 & 15 & 20 & 12 & 75 \\
\hline \multicolumn{6}{|l|}{ Dissolved Cd } \\
\hline Environmental Quality Standard $[\mu \mathrm{g} / \mathrm{L}]$ & 0.09 & 0.09 & 0.09 & 0.09 & 0.09 \\
\hline Pre-remediation concentration $\left[\mu \mathrm{g} \mathrm{L}^{-1}\right]$ & 2.88 & 2.88 & 2.88 & 2.88 & 2.88 \\
\hline Pre- remediation load $\left[\mathrm{mg} \mathrm{s}^{-1}\right]$ & 0.788 & 0.788 & 0.788 & 0.788 & 0.788 \\
\hline Load from source $\left[\mathrm{mg} \mathrm{s}^{-1}\right]$ & 0.216 & 0.120 & 0.154 & 0.097 & 0.586 \\
\hline Post- remediation load $\left[\mathrm{mg} \mathrm{s}^{-1}\right]$ & 0.563 & 0.658 & 0.625 & 0.681 & 0.192 \\
\hline Post-remediation concentration $\left[\mu \mathrm{g} \mathrm{L}^{-1}\right]$ & 2.08 & 2.43 & 2.31 & 2.52 & 0.71 \\
\hline Concentration change post-remediation [\%] & 20 & 18 & 20 & 18 & 77 \\
\hline
\end{tabular}

Pre-remediation and post-remediation calculations are for the last synoptic sampling point (WW-1733)

rainfall runoff events may be greatest in the lower part of the study area where surface mine wastes and potential diffuse sources of metals are present.

\section{Implications for Remediation}

The effect on stream metal concentrations of treating mine water inflows or minimising mine tailings erosion can be estimated using mass balance calculations. For $\mathrm{Zn}$ and $\mathrm{Cd}$, which appear to behave relatively conservatively in the study reach, this method can approximate concentration changes from remediation reasonably well. For $\mathrm{Pb}$, this approach may be limited due to the reactive behaviour of this element in the system under study. To investigate the potential effect of remediation on stream $\mathrm{Pb}$ concentrations, the use of a reactive solute transport model that incorporates geochemical processes such as adsorption, precipitation, and dissolution is recommended (Runkel 1998; Walton-Day et al. 2012).

We consider here five possible remediation scenarios to reduce $\mathrm{Zn}$ and $\mathrm{Cd}$ concentrations in the Wanlock Water: treatment of mine water from the (1) Bay Mine adit, (2) Glenglass Level, (3) Glenglass Level no. 2, (4) capping and revegetation of the Queensbury tailings pond to reduce surface erosion and subsurface leaching, and (5) capping of the Queensbury tailings pond and treatment of all three major mine water sources. Remediation of $\mathrm{Pb}$ sources is not considered due to the aforementioned problems with using the mass balance approach for this element. Effective inflow concentrations calculated for $\mathrm{Zn}$ and $\mathrm{Cd}$ for the stream segment encompassing Glenglass Level no. 2 (and the Meadowfoot Adit) indicate inflow concentrations from the Glenglass Level no. 2 are most responsible for the observed increase in loading along this stream segment. As a result, treatment of water from Meadowfoot Adit is not considered here.

A post-remediation load at the end of the study reach (WW-1733) can be calculated by subtracting the load attributed to the remediated source area from the pre-remediation load at the end of the study reach. Dividing this by the flow at the end of the study reach gives a post-remediation metal concentration. All remediation scenario calculations are shown in Table 1. It must be noted that the mass balance calculations assume that remediation removes $100 \%$ of the metal contaminants from the source area, which is unlikely, and that it does not modify the flow attributed to that zone.

Notwithstanding the remediation scenarios being based only on Q30 flow conditions, it can be seen that the different remediation scenarios could achieve quite variable decreases in $\mathrm{Zn} \mathrm{(12-75 \% )} \mathrm{and} \mathrm{Cd}(18-77 \%)$ concentrations, with the greatest improvement achieved under scenario \#5 where all major sources are considered. However, even under scenario \#5, the Wanlock Water is unlikely to meet EQS at the end of the study reach. Some degree of dilution will occur however before the Wanlock Water flows into the Crawick Water, which could improve water quality for affected downstream rivers, the Crawick Water ( $\mathrm{Cd}$ and $\mathrm{Zn}$ failure), and the River Nith (Cd failure).

Although remediation of $\mathrm{Pb}$ sources has not been considered here, it is likely that capping of the Queensbury tailings pond would significantly reduce erosion and 
transport of $\mathrm{Pb}$ to the stream, and hence reduce stream $\mathrm{Pb}$ concentrations (e.g. Edwards et al. 2016). The role of the braided wetland area (the main source of $\mathrm{Pb}$ ) in stream metal loading warrants further investigation as it is possible that this is an episodic source related to higher stream water velocities and flows that mobilise deposited $\mathrm{Pb}$-rich sediments and soils.

\section{Conclusions}

A tracer injection and synoptic sampling experiment was conducted in a $2 \mathrm{~km}$ reach of the Wanlock Water, Scotland, in September 2019 to investigate mine pollution sources and dynamics at high spatial resolution in a wet, temperate watershed. While the largest sources of dissolved $\mathrm{Zn}$ and $\mathrm{Cd}$ were point sources (drainage adits) in the upper part of the study area, the largest sources of total recoverable and dissolved $\mathrm{Pb}$ were diffuse sources (a braided wetland area and the Queensbury tailings pond) in the lower part of the study reach. These data are important as they suggest that diffuse sources of mine pollution (i.e. surface and subsurface drainage from tailings/wastes) may be relatively persistent in wet, temperate watersheds and not simply related to episodic and short-term rainfall-runoff events. Furthermore, mass balance calculations, using the high spatial metal loading datasets, suggest treatment of point sources of mine water and capping of the Queensbury tailings pond to minimise diffuse sources could decrease $\mathrm{Zn}$ and $\mathrm{Cd}$ concentrations by $>70 \%$. Although beneficial, these interventions would not be sufficient for the Wanlock Water study reach to meet EQS due to other diffuse sources of pollution in the area. However, remedial interventions could potentially improve river systems further downstream, allowing them to meet EQS.

The tracer dilution and synoptic sampling approach used in this study were successful at establishing streamflow and water chemistry at multiple sites across the Wanlock Water watershed over a timescale of a few hours. These data were then used to establish high spatial resolution loading profiles for mine pollution contaminants. These, in turn, were used to locate and quantify the major point and diffuse sources of mine pollution and to estimate potential water quality improvements from different mine site remediation scenarios. Such data are essential to inform remedial approaches aimed at achieving the environmental and socio-economic goals set out in watershed management plans.

Supplementary Information The online version contains supplementary material available at https://doi.org/10.1007/s10230-021-00792-0.

Acknowledgements This project was supported by the SEPA Research and Development fund as part of its R\&D work for novel water monitoring techniques to support identification of pollutant sources. We thank many SEPA staff from the Chemistry, Regulatory Services, Laboratory and National Monitoring Teams who supported the field sampling and laboratory analyses. We also thank the Buccleuch Queensbury Estate for allowing site access to undertake the fieldwork.

Open Access This article is licensed under a Creative Commons Attribution 4.0 International License, which permits use, sharing, adaptation, distribution and reproduction in any medium or format, as long as you give appropriate credit to the original author(s) and the source, provide a link to the Creative Commons licence, and indicate if changes were made. The images or other third party material in this article are included in the article's Creative Commons licence, unless indicated otherwise in a credit line to the material. If material is not included in the article's Creative Commons licence and your intended use is not permitted by statutory regulation or exceeds the permitted use, you will need to obtain permission directly from the copyright holder. To view a copy of this licence, visit http://creativecommons.org/licenses/by/4.0/.

\section{References}

Aiken GR, Hsu-Kim H, Ryan JN (2011) Influence of dissolved organic matter on the environmental fate of metals, nanoparticles, and colloids. Environ Sci Technol 45:3196-3201

Byrne P, Wood PJ, Reid I (2012) The impairment of river systems by metal mine contamination: a review including remediation options. Crit Rev Environ Sci Technol 42:2017-2077

Byrne P, Reid I, Wood PJ (2013) Stormflow hydrochemistry of a river draining an abandoned metal mine, the Afon Twymyn, central Wales. Environ Monit Assess 185:2817-2832

Byrne P, Runkel RL, Walton-Day K (2017) Synoptic sampling and principal components analysis to identify sources of water and metals to an acid mine drainage stream. Environ Sci Pollut R 24:17220-17240

Byrne P, Onnis P, Runkel RL, Frau I, Lynch SFL, Edwards P (2020) Critical shifts in trace metal transport and remdiation performance under future low river flow scenarios. Environ Sci Technol 54:15742-15750

Chen WB, Gueguen C, Smith DS, Galceran J, Puy J, Companys E (2018) Metal ( $\mathrm{Pb}, \mathrm{Cd}$, and $\mathrm{Zn}$ ) binding to diverse organic matter samples and implications for speciation modeling. Environ Sci Technol 52:4163-4172

De Giudici G, Medas D, Cidu R, Lattanzi P, Rigonat N, Frau I, Podda F, Marras PA, Dore E, Frau F, Rimondi V, Runkel RL, Wanty RB, Kimball B (2019) Assessment of origin and fate of contaminants along mining-affected Rio Montevecchio (SW Sardinia, Italy): a hydrologic-tracer and environmental mineralogy study. Appl Geochem 109:104420

Dean AP, Lynch S, Rowland P, Toft BD, Pittman JK, White KN (2013) Natural wetlands are efficient at providing long-term metal remediation of freshwater systems polluted by acid mine drainage. Environ Sci Technol 47:12029-12036

DEFRA (Department for Environment, Food and Rural Affairs) (2014) Water Framework Directive implementation in England and Wales: new and updated standards to protect the water environment. DEFRA, London

De Giudici G, Pusceddu C, Medas D, Meneghini C, Gianoncelli A, Rimondi V, Podda F, Cidu R, Lattanzi P, Wanty RB, Kimball BA (2017) The role of natural biogeochemical barriers in limiting metal loading to a stream affected by mine drainage. Appl Geochem 76:124-135

Dzombak DA, Morel FMM (1990) Surface complexation modelling: hydrous ferric oxide. Wiley, New York

Edwards P, Williams T, Stanley P (2016) Surface water management and encapsulation of mine waste to reduce water pollution from Frongoch Mine, mid Wales. In: Drebenstadt C, Michael P (eds) 
Proceedings of international mine water association symposium: mining meets water-conflicts and solutions, pp 546-553

Floyd JD (2003) Geology of the Leadhills District: a brief explanation of the geological map sheet 15E Leadhills. British Geological Survey, Keyworth

Gozzard E, Mayes WM, Potter HAB, Jarvis AP (2011) Seasonal and spatial variation of diffuse (non-point) source zinc pollution in a historically metal mined river catchment, UK. Environ Pollut 159:3113-3122

Hermann R, Neumann-Mahlkau P (1985) The mobility of zinc, cadmium, copper, lead, iron and arsenic in ground water as a function of redox potential and $\mathrm{pH}$. Sci Total Environ 43:1-12

Jarvis AP, Mayes WM (2012) Prioritisation of abandoned non-coal mine impacts on the environment: the National Picture. Environment Agency, Bristol

Jarvis AP, Davis JE, Orme PHA, Potter HAB, Gandy CJ (2019) Predicting the benefits of mine water treatment under varying hydrological conditions using a synoptic mass balance approach. Environ Sci Technol 53:702-709

Kimball BA, Runkel RL, Walton-Day K, Bencala KE (2002) Assessment of metal loads in watersheds affected by acid mine drainage by using tracer injection and synoptic sampling: Cement Creek, Colorado, USA. Appl Geochem 17:1183-1207

Lynch SFL, Batty LC, Byrne P (2017) Critical control of flooding and draining sequences on the environmental risk of $\mathrm{Zn}$-contaminated riverbank sediments. J Soils Sediments 17:2691-2707

Lynch SFL, Batty LC, Byrne P (2018) Environmental risk of severely $\mathrm{Pb}$-contaminated riverbank sediment as a consequence of hydrometeorological perturbation. Sci Total Environ 636:1428-1441

Mayes WM, Johnston D, Potter HAB, Jarvis AP (2009) A national strategy for identification, prioritisation and management of pollution from abandoned non-coal mine sites in England and Wales. Int Sci Total Environ 407:5435-5447

Onnis P, Byrne P, Hudson-Edwards KA, Stott T, Hunt C (2018) Source apportionment of trace metals over a range of stream flows using a multi-method tracer approach. In: Wolfersdorfer C, Sartz L, Weber A, Burgess J, Tremblay G (eds) Proceedings of international mine water association symposium: risk to opportunity, Water Institute of Southern Africa and International Mine Water Assoc, pp 843-848

Palumbo-Roe B, Wragg J, Banks VJ (2012) Lead mobilisation in the hyporheic zone and river bank sediments of a contaminated stream: contribution to diffuse pollution. J Soils Sediments 12:1633-1640

Pietroń J, Chalov SR, Chalova AS, Alekseenko AV, Jarsjö J (2017) Extreme spatial variability in riverine sediment load inputs due to soil loss in surface mining areas of the Lake Baikal basin. Catena 152:82-93

Rowan JS, Barnes SJA, Htherington SL, Lamber B (1995) Geomorphology and pollution: the environmental impacts of lead mining, Leadhills, Scotland. J Geochem Explor 52:57-65

Runkel RL (1998) One-dimensional transport with inflow and storage (OTIS): a solute transport model for streams and rivers. U.S. Geological Survey, Denver

Runkel RL, Walton-Day K, Kimball BA, Verplanck PL, Nimick DA (2013) Estimating instream constituent loads using replicate synoptic sampling, Peru Creek, Colorado. J Hydrol 489:26-41

Runkel RL, Kimball BA, Nimick DA, Walton-Day K (2017) Effects of flow regime on metal concentrations and the attainment of water quality standards in a remediated stream Reach, Butte, Montana. Environ Sci Technol 50:12641-12649

Scottish Environment Protection Agency (SEPA) (2011) Review of metal concentrations data held for Glengonnar Water and Wanlock Water, South Central Scotland, Scottish Environment Protection Agency. https://www.sepa.org.uk/media/163236/metals_gleng onnar_wanlock_waters_review.pdf. Accessed 18 Feb 2021

The Coal Authority (2014) The impacts of mining on the Wanlock Water, Wanlockhead, Dumfries and Galloway, The Coal Authority. https://www.sepa.org.uk/media/218986/impacts_mining_ wanlock_water.pdf. Accessed 12 Feb 2021

Thornton GJP, Walsh RPD (2001) Heavy metals in the waters of the Nant-y-Fendrod: change in pollution levels and dynamics associated with the redevelopment of the Lower Swansea Valley, South Wales, UK. Sci Total Environ 278:45-55

Walton-Day K, Paschke SS, Runkel RL, Kimball BA (2007) Using the OTIS solute-transport model to evaluate remediation scenarios in Cement Creek and the Upper Animas River. In: Church SE, Von Guerard P, Finger SE (eds) Integrated investigations of environmental effects of historical mining in the Animas River Watershed, San Juan County, Colorado, US Geological Survey

Walton-Day K, Runkel RL, Kimball BA (2012) Using spatially detailed water quality data and solute transport modelling to support total maximum daily load development. J Am Water Resour Assoc 48:949-969

Zhou GY, Wei XH, Chen XZ, Zhou P, Liu XD, Xiao Y, Sun G, Scott DF, Zhou SYD, Han LS, Su YX (2015) Global pattern for the effect of climate and land cover on water yield. Nat Commun 6:5918

Publisher's Note Springer Nature remains neutral with regard to jurisdictional claims in published maps and institutional affiliations. 